\title{
Ameliorative effects of olibanum essential oil on learning and memory in Aß1-42-induced Alzheimer's disease mouse model
}

\author{
Zhenzhen Zhang $^{1 *}$, Wenhua Chen ${ }^{2}$, Jie Luan ${ }^{1}$, Dagui Chen ${ }^{3}$, Lina Liu ${ }^{1}$, Xu Feng ${ }^{1}$ \\ ${ }^{1}$ Naval Medical Research Institute, Second Military Medical University, 880 Xiangyin Road, Shanghai 200433, ${ }^{2}$ School of \\ Pharmacy, Shandong University of Traditional Chinese Medicine, Jinan 250355, ${ }^{3}$ Institute of Translational Medicine, Shanghai \\ University, Shanghai 200444, China
}

*For correspondence: Email: zz_jane@126.com; Tel: (+86) 021-81883318

Sent for review: 28 September 2019

Revised accepted: 16 July 2020

\begin{abstract}
Purpose: To study the effect of olibanum essential oil (OEO) on learning and memory in Alzheimer's disease $(A D)$ mouse.

Methods: Mice were administered the 42-amino acid form of amyloid $\beta$-peptide (Aß1-42) to induce $A D$ and then treated with OEO at 150,300, and $600 \mathrm{mg} / \mathrm{kg}$, p.o. for two weeks. Following treatment, the $A D$ mice were assessed by step-down test (SDT), dark avoidance test (DAT), and Morris water maze test (MWM). Blood and brain tissues were collected for biochemical assessments. Gas chromatographymass spectroscopy was used to analyze the main constituents of OEO.

Results: The main constituents of OEO were limonene, $\alpha$-pinene, and 4-terpineol. Treatment with OEO prolonged $t$ latency in SDT and DAT, but decreased error times. Escape latency decreased and crossing times were rose in the MWM following OEO treatment $(p<0.5)$. Treatment with OEO also enhanced the acetylcholine levels and decreased the acetylcholinesterase levels in serum and brain tissue $(p<0.5)$. Additionally, OEO reduced amyloid plaques in the hippocampus and protected hippocampal neurons from damage. Furthermore, OEO decreased $c$-fos expression in hippocampus tissues from $A D$ mice ( $p<0.5)$.

Conclusion: OEO has significant ameliorative effect $A D$-induced deterioration in learning and memory in $A D$ mouse induced by $A \beta 1-42$. The mechanisms of these effects are related to increased acetylcholine contents, reduction of amyloid plaques, protection of hippocampal neurons, and downregulation of c-fos in brain tissues. The results justify the need for further investigation of candidate drugs derived from $O E O$ for the management of $A D$.
\end{abstract}

Keywords: Olibanum, Essential oil, Learning, Memory, $A D$

This is an Open Access article that uses a fund-ing model which does not charge readers or their institutions for access and distributed under the terms of the Creative Commons Attribution License (http://creativecommons.org/licenses/by/4.0) and the Budapest Open Access Initiative (http://www.budapestopenaccessinitiative.org/read), which permit unrestricted use, distribution, and reproduction in any medium, provided the original work is properly credited.

Tropical Journal of Pharmaceutical Research is indexed by Science Citation Index (SciSearch), Scopus, International Pharmaceutical Abstract, Chemical Abstracts, Embase, Index Copernicus, EBSCO, African Index Medicus, JournalSeek, Journal Citation Reports/Science Edition, Directory of Open Access Journals (DOAJ), African Journal Online, Bioline International, Open-J-Gate and Pharmacy Abstracts

\section{INTRODUCTION}

Alzheimer's disease (AD), a intractable senile diseases with multifactorial etiology, is currently considered the predominant factor of dementia $[1,2]$. Epidemiology investigations have shown that $A D$ currently affects nearly $50,000,000$ people in the world, and the number of $A D$ 
patients is estimated to triple during the next 30 years because of an increase in the older adult population [3,4]. More importantly, although the diagnostic technologies for $A D$ have improved considerably, there is still no decisive treatment or effective drug for $A D$ patients. The only available course of action is to delay the development of the pathologic process during its early stages $[5,6]$.

Consequently, finding more candidate agents for curing $A D$ is both important and urgent. Increasing numbers of research studies are focusing on the potential effects of natural monomers from plants or herbs to treat various intractable diseases; natural agents are precious resources for identifying novel monomers/extracts with promising pharmacological activities [7,8]. For examples, the known antitumor drug Taxol is a natural extract isolated from Taxus chinensis, and the promising antimalarial drug artemisinin is a sesquiterpene lactone extracted from the Artemisia annua.

Olibanum, the resin of the Boswellia serrata (Burseraceae), mainly distributed in India and Eastern Africa, and is a known folk medicine used for treating pain, inflammation, and swelling [9]. Furthermore, previous work indicates that agents or extracts of olibanum can effectively improve memory deficit in rats tested in a Morris water maze, which reflects the level of memory [9-11]. In addition, previous evidence revealed that the constituents of olibanum are mainly triterpenes, essential oils, and resin. The gum resin of olibanum combined with beta-boswellic acid (BBA) has long been used in Ayurveda (India's traditional medicine) for preventing amnesia by enhancing memory. In addition, studies have indicated that this natural essential oil is beneficial for improvement of learning and memory potentials of experimental AD rats [911]. So far, no previous investigation has focused on the effects of olibanum essential oil (OEO) on learning and memory abilities. The aims of this work were to research the beneficial effects of OEO on learning and memory in a $\beta$-amyloid peptide-induced $A D$ mouse model and to determine if there is significant value for further investigation of candidate drugs derived from $O E O$ to treat $A D$ in clinical.

\section{EXPERIMENTAL}

\section{Plant material}

Olibanum was purchased from the Tongrentang drug store (Shanghai, China) and authenticated by Dr. Ting Han (Department of Pharmacognosy, $2^{\text {nd }}$ Military Medical University (SMMU), Shanghai, China). A voucher specimen (no. S20180904) was kept in the specimen laboratory of the Naval Medical Research Institute, SMMU.

\section{Animals and ethics statement}

Experimental groups consisted of male ICR mice $(25-30 \mathrm{~g})$ were acquired from the CAVENS Animal Centre (Changzhou, China). Mice were housed under normal conditions $\left(22 \pm 2{ }^{\circ} \mathrm{C}\right.$ and $40-60 \%$ humidity) and had free access to water and diet. All animal protocols were strictly obeying the NIH Guide concerning the Care and Use of Laboratory Animals [12], and approved by the Ethics Committee of SMMU (approval no. 20190217an-1\#).

\section{Extraction of essential oil}

The OEO was extracted referenced the recorded method [13]. The olibanum powder (100g) was boiled in 15 times its volume of water for $8 \mathrm{~h}$. The distillate was extracted by $n$-hexane and subsequently dried using anhydrous sodium sulfate. The yield of OEO was $4.52 \%(\mathrm{v} / \mathrm{w})$. The essential oil was stored under $-10{ }^{\circ} \mathrm{C}$ until used in experimental assays.

\section{Gas chromatography-mass spectroscopy (GC-MS) analysis}

The OEO was dissolved in n-hexane to determine the constituents using an Agilent 7890 gas chromatograph combined with the Agilent 5975 mass spectrometer. The essential oil samples $(1.0 \mu \mathrm{L})$ were determined using a capillary column (DB-5MS, $30 \mathrm{~m} \times 0.25 \mathrm{~mm} \times$ $0.25 \mu \mathrm{m})$. The temperature program of the column used was bellow: for starting, $60{ }^{\circ} \mathrm{C}$ for 2 min, and subsequently increased to $100{ }^{\circ} \mathrm{C}(2$ $\left.{ }^{\circ} \mathrm{C} / \mathrm{min}\right)$, and then to $260{ }^{\circ} \mathrm{C}\left(10^{\circ} \mathrm{C} / \mathrm{min}\right) ; 260{ }^{\circ} \mathrm{C}$ was kept for $3 \mathrm{~min}$. The flow rate of carrier gas (helium) was $1.0 \mathrm{~mL} / \mathrm{min}$.

The split ratio used was set at $10: 1$, and the electron impact ionization was $70 \mathrm{eV}$ and the mass scanning range was 50 - 450 amu. Compounds were analyzed based on comparing the retention indices $(\mathrm{RI})$ to $n$-alkanes $\left(\mathrm{C}_{8}-\mathrm{C}_{40}\right)$, and further identified by searching the NIST database (USA).

\section{Protocols and grouping of animals}

A total of 60 ICR mice were divided into 5 groups randomly: normal, control, and three OEO testing groups (low dose, middle dose, and high dose). Each group consisted of 12 animals. The AD mouse model was induced by injection of $A \beta_{1-42}$ 
(Sigma-Aldrich, Shanghai, China) intracerebroventricularly (i.c.v.) according to a previously published method $[13,14]$. Briefly, the mice were anesthetized by sodium pentobarbital (SigmaAldrich) (50 mg/kg, i.p.). Subsequently, mice were fixed with a stereotaxic device (Yuyan Instruments, Shanghai, China). The $A \beta_{1-42}$ was dissolved in sterile normal saline to achieve a concentration of 1 . Next, $5 \mu \mathrm{L}$ of the $A \beta_{1-42}$ solution $(400 \mathrm{pmol} / \mu \mathrm{L})$ was injected into the bilateral ventricles using a Hamilton microsyringe. Normal mice received an equal volume of sterile saline using the same surgical procedure. Behavioral tests [step-down test (SDT), dark avoidance test (DAT), and Morris water maze test (MWM)] were carried out 2 weeks after $A \beta_{1-42}$ injection. During the 2 weeks, the $A D$ mice in the OEO treatment groups were administered OEO at 150, 300, or $600 \mathrm{mg} / \mathrm{kg}$. All drugs were administered orally, and doses were expressed as $\mathrm{mg} / \mathrm{kg}$. After the last treatment and the MWM test, under anesthetization (sodium pentobarbital, $40 \mathrm{mg} / \mathrm{kg}$, i.m.), blood samples were collected from the aorta abdominalis of mice anesthetized by sodium pentobarbital (50 $\mathrm{mg} / \mathrm{kg}$, i.p.). Following blood collection, mice were sacrificed by cervical dislocation, and the hippocampi were precisely separated from the brains for further biochemical assays.

\section{Step-down test (SDT)}

The SDT was performed following the reported method [15]. ICR mice were kept in a dark room for $40 \mathrm{~min}$ before the test. Then, the mice underwent the following adaptive training: mice were placed on a platform $(5.0 \times 5.0 \times 4.5 \mathrm{~cm})$, if the animal stepped down from the platform, the animal suffered an electric foot shock (36 V, AC). Then, the mice were placed back in the animal cage. After $24 \mathrm{~h}$, the formal experiment was carried out, and the latency of step down (latency) with the maximum latency time of $300 \mathrm{~s}$ and the step-down times (error times) were recorded.

\section{Dark avoidance test (DAT)}

The DAT was conducted as previously described with minor modifications [16]. The apparatus was equipped with two identical light and dark square boxes $(15 \times 15 \times 15 \mathrm{~cm})$. Similar to the SDT, the DAT consisted of a training trial and a formal test trial. For the training trial, animals were placed in the light box and, if the animal entered the dark box, the animal suffered a $0.5-\mathrm{mA}$ electric foot shock for $3 \mathrm{~s}$. After $24 \mathrm{~h}$, the formal experiment was carried out, and the darkness avoidance latency with a maximum latency time of $300 \mathrm{~s}$ and error times were recorded.

\section{Morris water maze test (MWM)}

The MWM test was performed using a previously reported method, with minor modifications [17]. The MWM apparatus consisted of a roundness pool $(50 \times 120 \mathrm{~cm})$ full of opaque water $(23 \pm 1$ ${ }^{\circ} \mathrm{C}$ ) with a depth of $18 \mathrm{~cm}$. The pool consisted of four equal quadrants, with a 5-cm diameter round a platform located $1.0 \mathrm{~cm}$ below the water surface. The MWM test consisted of four consecutive days of training sessions followed by a spatial probe test. During the training sessions to find the rounded platform, mice were trained in different quadrants four times each day for a maximum of $120 \mathrm{~s}$. For the spatial probe test, the platform was removed on the fifth day, and the escape latency to the original platform site and crossing times of the original platform site were recorded within a maximum of $180 \mathrm{~s}$.

\section{Enzyme-linked immunosorbent assay (ELISA)}

After the MWM test and the last treatment, mice were anesthetized (sodium pentobarbital, 50 $\mathrm{mg} / \mathrm{kg}$, i.m.) and blood samples were collected from the aorta abdominalis. Serum was prepared by centrifugation $\left(2000 \mathrm{~g}, 4^{\circ} \mathrm{C}, 10 \mathrm{~min}\right)$. Subsequently, brain was excised under ice and divided into two parts. One part was used to further separate the hippocampus tissue that was stored in $10 \%$ neutral formaldehyde solution (Solarbio Life Sci, Beijing, China) for further histopathological examination. The remaining brain part was homogenized, and the supernatants were collected for ELISA. The levels of acetylcholine (Ach) and acetylcholinesterase (AchE) in brain tissues and serum were determined using commercial ELISA assay kits using the standard processing (Multi Sci. Co., Hangzhou, China).

\section{Histopathological examination}

The hippocampus was fixed in neutral formaldehyde $(10 \%)$, and embedded in paraffin. Subsequently, paraffin blocks were sectioned into 5- $\mu \mathrm{m}$ slices, de-paraffinized, and stained with Congo Red (Solarbio Life Sci, Beijing, China) and hematoxylin-eosin (H\&E) (Solarbio Life Sci, Beijing, China) or H\&E alone. Finally, the hippocampus tissues sections were observed tieh an optical microscope (Olympus, Tokay, Japan).

\section{Immunohistochemical assay}

The hippocampus sections $(5 \mu \mathrm{m})$ were routinely de-paraffinized, incubated with $3 \% \mathrm{H}_{2} \mathrm{O}_{2}$ for 10 min, and boiled in $0.01 \mathrm{M}$ citric acid buffer (5 $\mathrm{min})$. After blocking by goat serum for $30 \mathrm{~min}$, 
sections were probed with antibodies of c-fos (Abcam Biotechnology, Cambridge, MA, USA; 1:2000) overnight $\left(4^{\circ} \mathrm{C}\right)$. Next, a secondary antibody (Abcam Biotechnology) was used and the peroxidase label was visualized by incubating with 3,3'-diaminobenzidine tetrachloride (Beyotime Biotechnology, Haimen, China). The immunohistochemical changes in c-fos in hippocampus were observed by optical microscope.

\section{Statistical analysis}

Data are presented as mean \pm standard deviation (SD), and were analyzed by one-way analysis of variance (ANOVA) followed by Dunnett's multiple comparison test with the aid of SPSS. Differences were considered statistically significant at $p<0.05)$.

\section{RESULTS}

\section{Chemical composition of essential oil from Olibanum}

The total ion chromatogram of OEO is shown in Figure 1. Ten constituents account for $87.44 \%$ of the total constituents. The essential oils of olibanum were identified using GC-MS analysis. The identified constituents and their composition percentages are presented in Table 1. The main components of OEO are $\alpha$-pinene (59.4\%), limonene $(10.5 \%), \quad \beta$-thujene $(3.73 \%)$, sabenene $(2.92 \%)$, p-cymene $(2.76 \%)$, and myrcene $(2.25 \%)$.

\section{Effect of OEO on behavior of AD mice in the step-down test}

Results of the SDT are shown in Figure 2. Compared to normal mice, the step-down latency of $A D$ model mice (Control) is shorter $(p<0.01)$, whereas the number of errors are increased $(p<$
0.01). However, compared to control mice, treatment with the OEO at the low, middle, and high doses significantly prolonged the step-down latency of $A D$ mice $(p<0.05, p<0.01, p<0.01)$, and decreased the number of errors $(p<0.05, p$ $<0.01, p<0.01$ ).

\section{Effect of OEO on behavior of AD mice in the dark avoidance test}

The results of the DAT are summarized in Figure 3. Overall, the results of the DAT are similar to those of the SDT. In the DAT, the latency of the $A D$ mice (control mice) was significantly decreased compared to the normal mice ( $p<$ 0.01 ), whereas the number of errors were increased $(p<0.01)$. Interestingly, administration of OEO (low, middle, and high doses) prolonged the dark avoidance latency $(p<0.05, p<0.01, p$ $<0.01$, ) and decreased the number of errors $(p<$ $0.05, p<0.01, p<0.01)$ compared to the $A D$ mice.

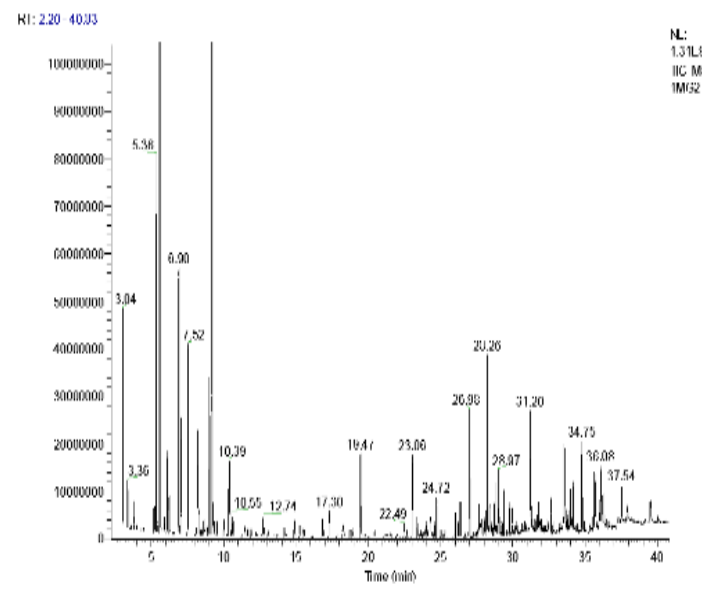

Figure 1: Total ion chromatogram of essential oil from olibanum

Table 1: Chemical composition of Olibanum essential oil

\begin{tabular}{lcccc}
\hline No. & Compound & $\boldsymbol{t}_{\boldsymbol{R}}$ & Content (\%) & RI \\
\hline $\mathbf{1}$ & $\beta$-thujene & 5.36 & 3.73 & 928 \\
$\mathbf{2}$ & $\alpha$-pinene & 5.64 & 59.4 & 938 \\
$\mathbf{3}$ & Camphene & 6.11 & 1.65 & 951 \\
$\mathbf{4}$ & Sabenene & 6.90 & 2.92 & 975 \\
$\mathbf{5}$ & $\beta$-Pinene & 7.07 & 1.72 & 978 \\
$\mathbf{6}$ & Myrcene & 7.52 & 2.25 & 988 \\
$\mathbf{7}$ & $\alpha$-Phellandrene & 8.2 & 1.54 & 1166 \\
$\mathbf{8}$ & 3-Carene & 8.27 & 0.97 & 1014 \\
$\mathbf{9}$ & p-Cymene & 9.00 & 2.76 & 1027 \\
$\mathbf{1 0}$ & Limonene & 9.21 & 10.5 & 1031 \\
& Total identified (\%) & & 87.44 & \\
\hline
\end{tabular}

$\mathrm{RI}$ : retention indices relative to $\mathrm{n}$-alkanes $\mathrm{C}_{8}-\mathrm{C}_{40}$ on HP-5MS column; Cont.: contents; $t_{R}$ : retention time 
(a)

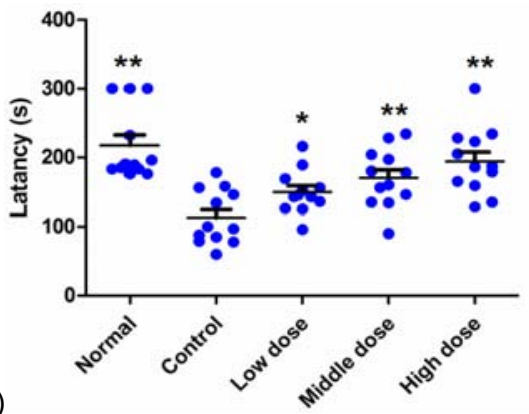

(b)

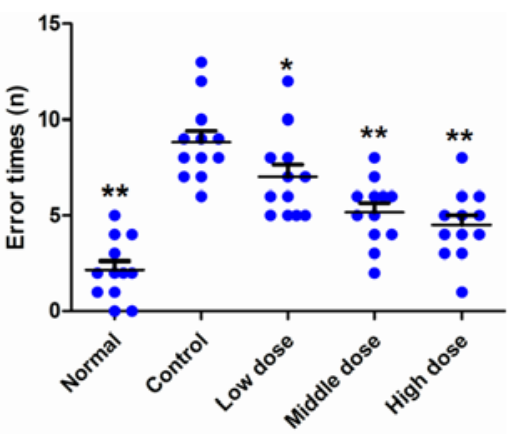

Figure 2: Effect of OEO on learning and memory impairment in $A D$ mice during the step-down test: (a) Latency and (b) Error times. Data are expressed as mean $\pm S D(n=12),{ }^{*} p<0.05,{ }^{* *} p<0.01$, vs. control

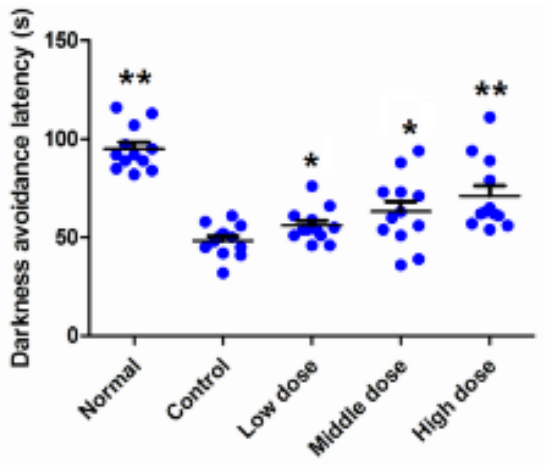

(a)

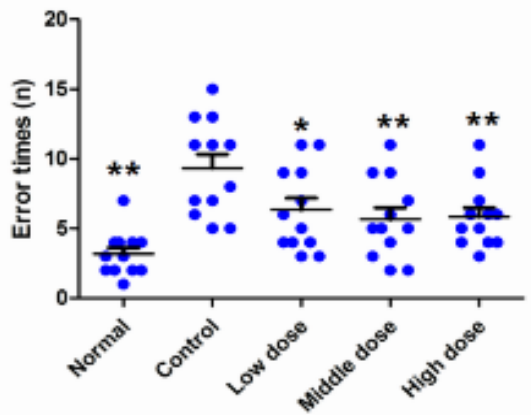

(b)

Figure 3: Effect of OEO on learning and memory impairment of $A D$ mice in the dark avoidance test. (a) Darkness avoidance latency, (b) Error times. Data are expressed as mean \pm SD $(\mathrm{n}=12),{ }^{*} p<0.05,{ }^{* *} p<$ 0.01 , vs. control Effect of OEO on behavior of $A D$ mice in
morris water maze test

The MWM test was also used to determine the effects of OEO on learning and memory impairment in $A D$ mice. After injection of $A \beta_{1-42}$, the escape latency of $A D$ mice (control mice) was significantly prolonged $(p<0.01)$ compared to normal mice, whereas the number of crossings were decreased $(p<0.01)$. Interestingly, OEO treatment at low, middle, and high doses significantly reduced the escape latency $(p<$ $0.05, p<0.01, p<0.01)$ and increased the number of crossings $(p<0.05, p<0.05, p<$ $0.05)$ compared to AD mice (Figure 4).

(a)

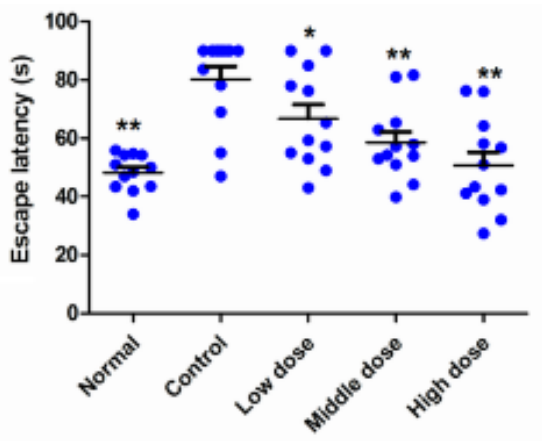

(b)

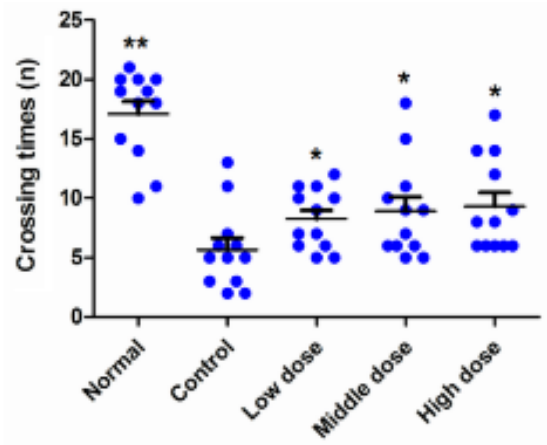

Figure 4: Effects of OEO on learning and memory impairment of $A D$ mice in the Morris water-maze test. (a) Escape latency, (b) Crossing times. Data are expressed as mean $\pm \operatorname{SD}(\mathrm{n}=12),{ }^{*} p<0.05,{ }^{*} p<0.01$, vs. control

\section{Effect of OEO on Ach and AchE in serum and brain tissues of AD mice}

Results of neurotransmitter (Ach and AchE) levels in serum and brain tissue are exhibited in Figure 5. After injection of $A \beta_{1-42}$, the levels of Ach in serum and brain tissues of $A D$ mice were reduced $(p<0.01)$ and the AchE levels were increased $(p<0.01)$ compared to normal mice. Interestingly, administration of OEO at low, middle, and high doses $(p<0.01)$ enhanced the Ach levels in serum of AD mice and $(p<0.01)$ reduced the AchE levels in serum compared to 
control mice. Treatment with OEO at middle and high doses also significantly increased the Ach levels $(p<0.01)$ and decreased the AchE levels in brain tissues of AD mice $(p<0.05$ and $p<$ $0.01)$ compared to control mice.
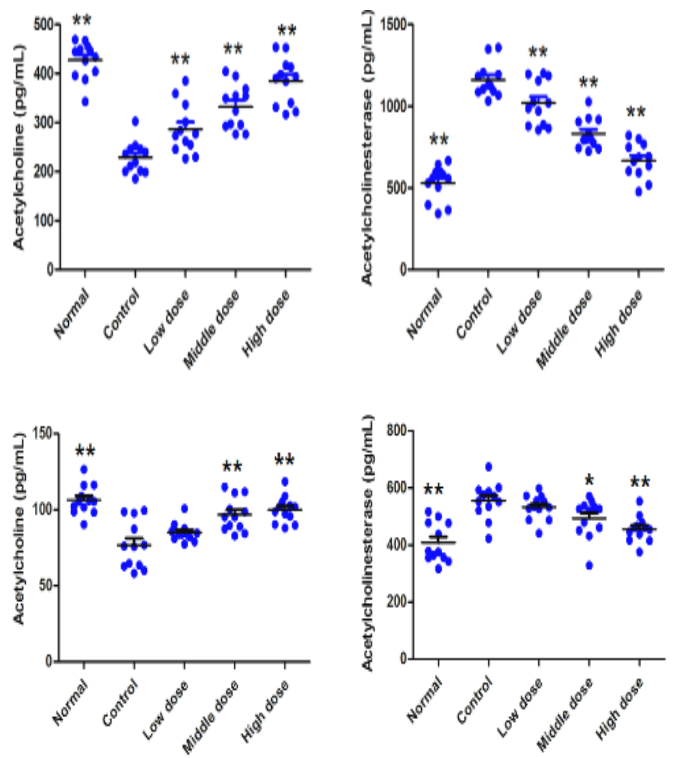

Figure 5: Effect of OEO on acetylcholine (Ach) and acetylcholinesterase (AchE) in serum (a) and brain tissues (b) of AD mice. Data are expressed as mean \pm $\mathrm{SD}(\mathrm{n}=12) .{ }^{*} p<0.05,{ }^{* *} p<0.01$, vs. control

\section{Effect of OEO on histopathological changes of AD mice}

The results of the histopathological examination are exhibited in Figure 6. Normal mice had intact hippocampal neurons with a clear structure that were arranged neatly with normal round cell nuclei. Obvious pathological changes were noted in the hippocampus of AD mice, such as wrinkled cells with irregular or abnormal nuclei and cells arranged in a disorderly manner. Interestingly, OEO treatment at low, middle, and high doses protected the hippocampal neurons from damage. In particular, no obvious pathological changes could be found in the high dose of OEO-treated mice compared to normal mice.

The results of Congo red staining, carried out to examine amyloid plaques in hippocampus tissues, are shown in Figure 7. No significant amyloid plaques were observed in the hippocampus tissues of normal mice. However, many obvious amyloid plaques (red staining) were found in hippocampus tissues of AD mice in the control group. After treatment with different doses of OEO, the amyloid plaques in hippocampus tissues were alleviated.
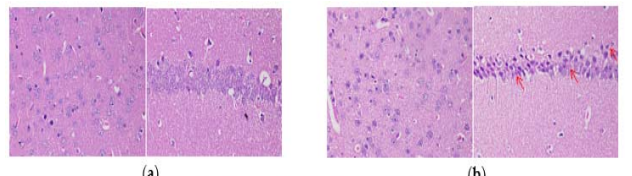

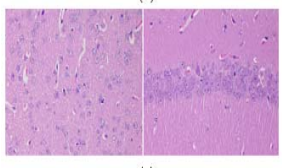

$(\mathbf{c})$
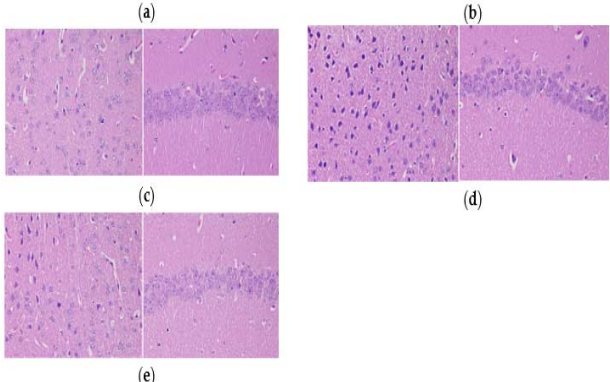

Figure 6: Morphology of H\&E-stained hippocampus tissues in $A D$ mice. a-e represent normal, control, and OEO (low, middle, and high dose) groups, respectively

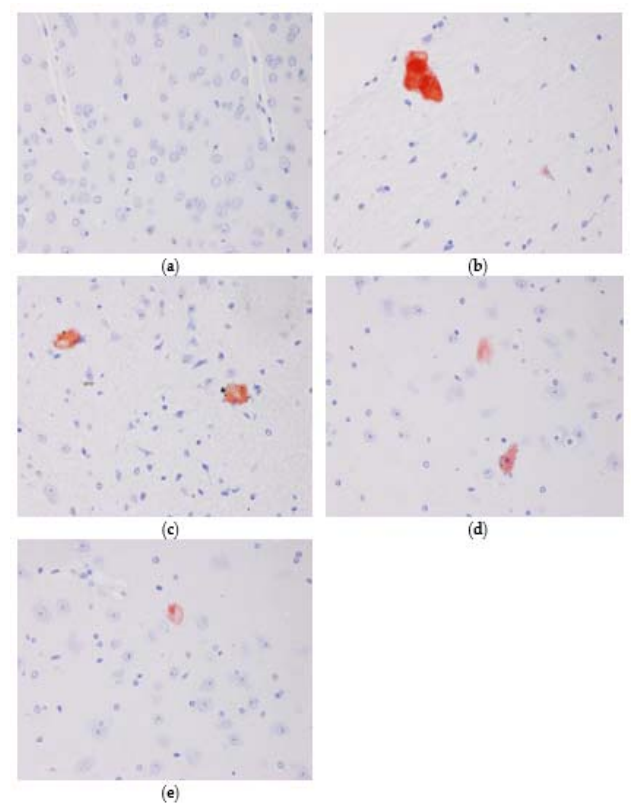

Figure 7: Morphology of Congo red-stained hippocampus tissues in $A D$ mice. a-e represent the normal, control, and OEO (low, middle, and high dose) groups, respectively

\section{Immunohistochemical results}

To determine the possible mechanisms of action of OEO against $A D$, an immunohistochemical assay with anti-c-fos antibody was conducted (Figure 8). After injection of $A \beta_{1-42}$, the population of c-fos positive cells in hippocampus tissues of AD mice was increased compared to normal mice. Interestingly, the OEO treatment at low, middle, and high doses effectively decreased cfos expression in hippocampus tissues of $A D$ mice compared to control mice in a dosedependent manner. 


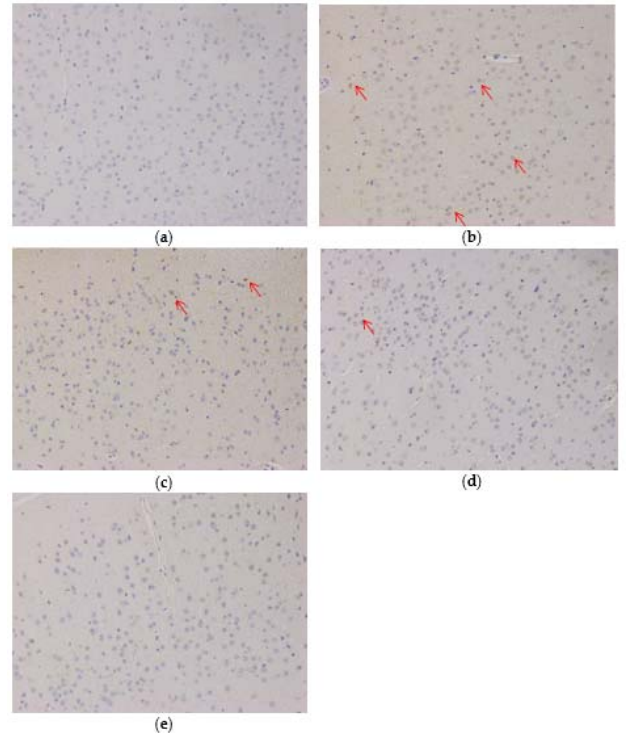

Figure 8: Immunohistochemical results for anti-c-fos antibody-stained hippocampus tissues in AD mice; a-e represent the normal, control, and OEO (low, middle, and high dose) groups, respectively. The arrows show the positive cells

\section{DISCUSSION}

Plant-derived natural extracts/monomers are precious resources for identifying novel chemical agents with potential medicinal properties [1722]. As part of the continuous involvement in finding novel potential bioactive agents for treating $A D$ from natural constituents, OEO was screened as a useful agent for reducing learning and memory impairment in $A D$ mice. This study is the first systematic report regarding the beneficial effects of OEO on learning and memory in $A D$ mouse resulted in the $A \beta_{1-42}$. Furthermore, the main constituents of OEO were identified as limonene, $\alpha$-pinene, 4-terpineol, $\beta$ elemene, sabinene, $p$-cymene, $\gamma$-terpinene, $\beta$ pinene, $(\mathrm{E})$-caryophyllene, and calamenene.

Animal behavioral experiments are useful and reliable ways of evaluating the effects of candidate drugs on cognitive functions [23]. The neurodegenerative disease $A D$ is characterized by cognitive dysfunction, which commonly results in deterioration of memory and difficulties in learning $[6,24]$. The SDT, DAT, and MWM tests are applied to study the curative effects of candidate drugs on AD-induced deterioration of memory and learning.

The results show that OEO treatment prolongs the latency in the SDT and DAT, but decreases the number of errors. In addition, OEO treatment reduced the escape latency and increased the number of crossings in the MWM test. These results indicate that OEO could alleviate the impaired cognitive functions of $A D$ mice. The deterioration of memory and learning is closely related to the reduction of Ach in the brain of $A D$ patients compared to healthy people [25]. In addition, because AchE is the enzyme used for hydrolysis of Ach in the human body, a decrease in AchE content could be beneficial for increasing Ach levels in the brain [26]. Interestingly, the present results indicate that OEO could enhance the Ach levels and decrease the AchE levels in serum and brain tissues. Increasing investigations have suggested that $A \beta$ accumulation plays a crucial role in $\operatorname{AD}[5,6,27]$.

The results of this study show that OEO treatment reduces the amyloid plaque in hippocampal tissues. Furthermore, the pathological examination results indicate that OEO treatment could protect the hippocampal neurons from damage. Previous studies have revealed that $\mathrm{c}$-fos is over-expressed in the brain tissues of $A D$ patients and plays an important role in $A D$ pathogenesis $[28,29]$. Importantly, the results also demonstrate that the OEO treatment could effectively decrease c-fos expression in hippocampus tissues of AD mice.

\section{CONCLUSION}

The findings of this study reveal that OEO has a significant beneficial effect on AD-induced deterioration of learning and memory in $A \beta_{1-42-}$ induced $A D$ mice. The possible mechanisms are related to increase in Ach content, reduction of amyloid plaques in brain tissue, protection of hippocampal neurons, and down-regulation of cfos in brain tissue. Thus, CEO has potentials for the management $A D$, but further investigations are required to ascertain this.

\section{DECLARATIONS}

\section{Acknowledgement}

This research was funded by the Guide Line for the Technical Standard Program of the Science and Technology Innovation Action Plan (grant no. 16DZ0501400). The funder had no role in study design; in the collection, analyses, or interpretation of data; in the manuscript preparation; or in the decision to publish the results. The authors thank Dr Diya Lv for technical assistance.

\section{Conflicts of interest}

No conflict of interest is associated with this work. 


\section{Contribution of authors}

We declare that this work was done by the authors named in this article and all liabilities pertaining to claims relating to the content of this article will be borne by the authors. Conceptualization, ZZ and XF; Data curation, WC, JL, and LL; Formal analysis, XF; Funding acquisition, XF; Investigation, ZZ, WC, JL, and DC; Methodology, ZZ; Project administration, DC and LL; Resources, XF; Writing - original draft, ZZ; Writing - review and editing, XF. All authors have read and approved the final manuscript.

\section{Open Access}

This is an Open Access article that uses a funding model which does not charge readers or their institutions for access and distributed under the terms of the Creative Commons Attribution License (http://creativecommons.org/licenses/by/ 4.0) and the Budapest Open Access Initiative (http://www.budapestopenaccessinitiative.org/rea d), which permit unrestricted use, distribution, and reproduction in any medium, provided the original work is properly credited.

\section{REFERENCES}

1. Di Resta C, Ferrari M. New molecular approaches to Alzheimer's disease. Clin Biochem 2019, doi: 10.1016/j.clinbiochem.2019.04.010.

2. Vöglein J, Noachtar S, McDade E, Quaid K, Salloway S, Ghetti, B, Noble J, Berman S, Chhatwal J, Mori H. Seizures as an early symptom of autosomal dominant Alzheimer's disease. Neurobiol Aging 2019; 76: 18-23.

3. Mokhtari Z, Baluchnejadmojarad T, Nikbakht F, Mansouri $M$, Roghani M. Riluzole ameliorates learning and memory deficits in AR25-35-induced rat model of Alzheimer's disease and is independent of cholinoceptor activation. Biomed Pharmacother 2017, 87: 135-144.

4. Thakur A, Chun Y.S, October N, Yang H.O, Maharaj V. Potential of South African medicinal plants targeting the reduction of $A \beta 42$ protein as a treatment of Alzheimer's disease. J Ethnopharmacol 2019; 231: 363-373.

5. Veitch DP, Weiner MW, Aisen PS, Beckett LA, Cairns NJ, Green $R C$, Harvey $D$, Jack $C R$ Jr, Jagust $W$, Morris JC, et al. Understanding disease progression and improving Alzheimer's disease clinical trials: Recent highlights from the Alzheimer's Disease Neuroimaging Initiative. Alzheimers Dement 2019; 15: 106-152.

6. Alzheimer's Association. 2019 Alzheimer's disease facts and figures. Alzheimers Dement 2019; 15: 321-387.

7. Long Y, Yang QY, Xiang Y, Zhang YL, Wan JY, Liu SY, Li N, Peng W. Nose to brain drug delivery - a promising strategy for active components from herbal medicine for treating cerebral ischemia reperfusion. Pharmacol. Res. 2020, 159: 104795

8. Lu GY, Luo XL, Liu ZQ, Yang L, Lin C, Xu M. Protective effect of vanillin in streptozotocin-induced diabetes in neonatal rats via attenuation of oxidative stress and inflammation. Trop J Pharm Res 2019; 18: 349-355.

9. Chang Y, Han Y, Zhang JY. Research advance on chemical constituents and pharmacological action of Boswellia carterii. Drug Clin 2012; 27: 52-59.

10. Postu PA, Sadiki FZ, El Idrissi M, Cioanca O, Trifan A, Hancianu M, Hritcu L. Pinus halepensis essential oil attenuates the toxic Alzheimer's amyloid beta (1-42)induced memory impairment and oxidative stress in the rat hippocampus. Biomed Pharmacother 2019; 112: 108673.

11. Hosseini M, Hadjzadeh MA, Derakhshan M. The beneficial effects of olibanum on memory deficit induced by hypothyroidism in adult rats tested in morris water maze. Arch Pharm Res 2010; 33: 463-468.

12. NIH (National Institutes of Health U.S.A). Guide for the Care and Use of Laboratory Animals. Washington, D.C.: The National Academies Press. 2011, pp. 246

13. Farias WC, Ferreir HD, Sá S, Cunha LC, Neto J, Borges LL, Paula JR, Fiuz TS. Evaluation of the chemical composition and variability of the volatile oils from Trembleya parviflora leaves. Rev Bras Farmacogn 2018; 28: 414-420.

14. Sadiki FZ, Idrissi ME, Cioanca O, Trifan A, Hancianu M, Hritcu L, Postu PA. Tetraclinis articulata essential oil mitigates cognitive deficits and brain oxidative stress in an Alzheimer's disease amyloidosis model. Phytomed 2019; 56: 57-63.

15. Zhu L, Zhang L, Zhan L, Lu X, Peng J, Liang L, Liu Y, Zheng L, Zhang F, Liu Q. The effects of Zibu Piyin Recipe components on scopolamine-induced learning and memory impairment in the mouse. J Ethnopharmacol 2014; 151: 576-582.

16. Li H, Kang T, Qi B, Kong L, Jiao Y, Cao Y, Zhang J, Yang $J$ J Neuroprotective effects of ginseng protein on PI3K/Akt signaling pathway in the hippocampus of $D$ galactose/AICl3 inducing rats model of Alzheimer's disease. J Ethnopharmacol 2016; 179: 162-169.

17. Ji $X$, Shi S, Liu B, Shan $M$, Tang $D$, Zhang $W$, Zhang $Y$, Zhang $\mathrm{L}$, Zhuang $\mathrm{H}$, Lu C, et al. Bioactive compounds from herbal medicines to manage dyslipidemia. Biomed Pharmacother 2019; 118: 109338.

18. Meng YQ, Zhao YW, Kuai ZY, Liu LW, Li W. Synthesis and antitumor activity evaluation of novel oleanolic acid derivatives. J Asian Nat Prod Res 2017; 19: 1000-1010.

19. Zappavigna S, Vanacore D, Lama S, Potenza N, Russo $A$, Ferranti $P$, Dallio M, Federico A, Loguercio C, Sperlongano $P$, et al. Silybin-induced apoptosis occurs in parallel to the increase of ceramides synthesis and miRNAs secretion in human hepatocarcinoma cells. Int J Mol Sci 2019; 20: 2190.

20. Gou KJ, Zeng R, Ren XD, Dou QL, Yang QB, Dong Y, Qu Y. Anti-rheumatoid arthritis effects in adjuvantinduced arthritis in rats and molecular docking studies of

Trop J Pharm Res, August 2020; 19(8): 1650 
Polygonum orientale L. extracts. Immunol Lett 2018; 201: 59-69.

21. Howes MR, Fang R, Houghton PJ. Effect of Chinese Herbal Medicine on Alzheimer's Disease. Int Rev Neurobiol 2017; 135: 29-56.

22. Jin $X C$, Zhang L, Wang $Y$, Cai $H B$, Bao $X J$, Jin $Y Y$, Zheng GQ. An overview of systematic reviews of Chinese herbal medicine for Parkinson's disease. Front Pharmacol 2019; 10: 155.

23. Gannon TA. Forensic psychologists should use the behavioral experiment to facilitate cognitive change in clients who have offended. Aggress Viol Behav 2016; 27: 130-141.

24. Delkhosh-Kasmaie F, Farshid AA, Tamaddonfard E, Imani $M$. The effects of safranal, a constitute of saffron, and metformin on spatial learning and memory impairments in type-1 diabetic rats: behavioral and hippocampal histopathological and biochemical evaluations. Biomed Pharmacother 2018; 107: 203-211.

25. Liu G, Wen Z.L, He WB, Chen NH. Development of experiment on treating Alzheimer's disease with Bushen
Compound. Chin J Exp Trad Med Formul 2016; 22: 182188.

26. Hudgins PM, Stubbins JF. Interactions of acetylcholine mustard with acetylcholinesterase. J Pharm Sci 1975; 64: 1419-1421.

27. Wang $Y$, Wang $M$, Fan $K, L i T$, Yan $T, W u$, BK, Jia $Y$. Protective effects of Alpinae Oxyphyllae Fructus extracts on lipopolysaccharide-induced animal model of Alzheimer's disease. J Ethnopharmacol 2018; 217: 98106.

28. Wang YC, Wang ZD, He SC, Zheng H, Bai ZQ. Brain Cfos gene expression in two rat models of Alzheimer's disease and vascular dementia: a comparative study. Chin J Clin Rehab 2003; 7: 3802-3803.

29. Brown A, Thapa M, Hooker J, Ostrowski T. Impaired chemoreflex correlates with decreased c-Fos in respiratory brainstem centers of the streptozotocininduced Alzheimer's disease rat model. Exp Neurol 2019; 311: 285-292. 